\title{
HUDEBNÍ AKTIVITY UKRAJINCŮ V MEZIVÁLEČNÉM BRNĚ
}

Nositeli hudebního života moravské metropole v období mezi dvěma světovými válkami byly především vůdčí národnosti tohoto města, tedy Češi a Němci. Nebylo však žádným překvapením, že jsme při mapování komplexního koncertního a operního provozu meziválečného Brna nalezli také poměrně velké množství hudebních aktivit jiných etnik. V prrípadě Ukrajinců sice není rozsah jejich koncertního života zdaleka srovnatelný s aktivitami, které ve stejné době vyvíjeli př́slušníci tohoto národa $\mathrm{v}$ Praze, přesto však i zde nacházíme několik pozoruhodných momentů hodných zaznamenání. Jsme si vědomi toho, že tematika, kterou v této studii sledujeme, je velmi úzce specializovaná. Žrejmě z tohoto důvodu jí v hudební historiografii nebyla dosud věnována žádná pozornost. Domníváme se však, že zmapování této problematiky bude jedním z důležitých příspěvků pro budoucí komplexní zhodnocení neobyčejně širokého a rozsáhlého tématu, kterým je fenomén ukrajinské hudební emigrace do meziválečného Československa.

Hudební aktivity Ukrajinců v meziválečném Brně je možné rozdělit do dvou větších skupin. První z nich jsou koncerty Ukrajinské republikové kapely v roce 1919, kdy vlastní hudební kulturu v Brně šířili Ukrajinci, kteří na našem území nebyli dlouhodobě usazení, druhou skupinu pak tvoří koncertní vystoupení, jež byla pořádána místně př́íslušnými ukrajinskými emigrantskými spolky a sdruženími.

\section{Ukrajinská republiková kapela v Brně}

Fenomén československých turné Ukrajinské republikové kapely a jejich významu pro budování ukrajinské státnosti po první světové válce je tématem na samostatnou studii. Na tomto místě tedy zmiňme jen to nejdůležitější. I přes nepřesné označení ,kapela“ šlo o smíšený pěvecký sbor bez instrumentální slož-

1 V literatuře se setkáváme takřka jen s názvem „Ukrajinská republikánská kapela“, jenž je dobově podmíněným doslovným překladem skutečného názvu sboru „Українська республіканська капела“. Soubor však reprezentoval novou republiku a nikoliv republikánství jako takové, proto považujeme za vhodnější označovat toto těleso zvoleným způsobem. 
ky, který vznikl z iniciativy předsedy direktoria a hlavního atamana vojsk Ukrajinské lidové republiky Simona Petljury. Důvodem vzniku tělesa byla zahraniční propagace nově vzniklého národního státu a jeho kultury. Potřeba založit sbor tedy vyplývala spíše z politických než z uměleckých potřeb. Členové tělesa měli status státních zaměstnanců Ukrajinské lidové republiky a byli placeni z republikového rozpočtu. Uměleckým vedoucím kapely byl jmenován žák Mykoly Lysenka, skladatel a hudební pedagog Olexandr Košyc (1875-1944). ${ }^{2} \mathrm{~V}$ březnu 1919 odjela Kapela z Kamence-Podolského, jenž byl tehdy dočasně hlavním městem Ukrajinské lidové republiky, na turné do Československa s první zastávkou v Užhorodu. V květnu těleso opakovaně vystupovalo v Praze, poté se vydalo na cestu po českých a moravských městech; navštívilo Plzeň, Brno, Prostějov, Olomouc, Chrudim, Turnov, Mladou Boleslav a Jičín. Pásma téměř osmdesátičlenného sboru sestávala především ze sborových úprav ukrajinských lidových písní, ale také z děl Mykoly Lysenka a soudobých ukrajinských skladatelů (Oleksandr Košyc, Kyrylo Stecenko, Mykola Leontovyč).

Česká veřejnost byla $\mathrm{v}$ té době velmi málo informována o specifikách ukrajinského národa, který mnohým splýval s národem ruským. Kapela svou aktivitou v Československu tedy zcela splnila svůj misijní úkol, pro jehož vykonání byla založena - její vystoupení skutečně rozbila mnohé předsudky, a tím výrazně pozměnila vnímání ukrajinského národa $\mathrm{v}$ českých zemích. Československá vystoupení Kapely zaznamenala výrazný zájem a ohlas publika a také až nezvykle vstř́íné přijetí u kritiky. Výstupy tělesa $\mathrm{v}$ tisku reflektoval např. Josef Hutter, Jaroslav Křička, Josef Bartoš či Zdeněk Nejedlý, který dokonce o kapele napsal samostatnou knihu; ${ }^{3}$ ta představuje vůbec první ucelenou odbornou reflexi ukrajinské hudební kultury v českém prostředí. Ukrajinské písně se díky tomuto sboru staly v Československu načas módou - zněly v kavárnách i na ulicích, vzrostl zájem o tanec kozáček, čeští sbormistři přejímali některé Košycovy manýry vedení sboru a zařazovali do svého repertoáru ukrajinské písně. ${ }^{4}$

Po koncertech v Československu se sbor vydal do Rakouska, kde ve Vídni a Badenu koncertoval od konce července do začátku ř́ijna 1919. ${ }^{5}$ Po Rakousku následovalo Švýcarsko, poté Francie, Belgie, Nizozemí a dále Německo, kde se skupina v červnu 1920 rozpadla. ${ }^{6} \mathrm{Z}$ tělesa vznikly tři skupiny; první vedl Oleksa

2 KALINA, Petr Ch. Košyc, Oleksandr Antonovyč. In Český hudební slovník osob a institucí [online]. [Cit. 26. 9. 2013]. Dostupné z: $<$ http://www.ceskyhudebnislovnik.cz/slovnik/index. php?option $=$ com_mdictionary\&action=record_detail\&id=1003925>.

3 NEJEDLÝ, Zdeněk. Ukrajinská republikánská kapela. Kyjev-Praha: Čas, 1920.

4 KALINA, Petr Ch. Ukrajinská republiková kapela. In Český hudební slovník osob a instituci [online].[Cit. 26. 9. 2013]. Dostupné z: <http://www.ceskyhudebnislovnik.cz/slovnik/index. php?option $=$ com_mdictionary\&action=record_detail\&id=1003929>.

БЕЗРУЧКО, Леонід. Українська республіканська капела. Спогади з кониертної подорожі по Свропі. Народна воля - The people’s will. Скрентон, 9. 4. 1932, № 41, s. 3.

6 VESELÁ, Jitka. Ukrajinská republikánská kapela a její působení v Československu v roce 1919. Bakalářská diplomová práce, Univerzita Karlova v Praze, Filozofická fakulta, Ústav slavistických a východoevropských studií. Praha 2010. Vedoucí práce: Tereza Chlaňová. 
Prychod'ko, a ta odcestovala do Užhorodu. Druhá skupina, kterou vedl Jurko Kiričenko, odjela do Španělska. Poslední pod vedením Oleksandra Košyce zamířila do Turnova. Právě tato Košycova skupina se jako jediná ještě jednou vrátila do Československa. Po několika koncertech zde (Turnov, Německé Jablonné, Mladá Boleslav, Dvůr Králové nad Labem, Praha) odcestovali sboristé pod jménem Ukrajinský národní soubor do Varšavy a následně opět hostovali ve státech západní Evropy. V roce 1923 odjeli do Spojených států amerických, poté koncertovali v Mexiku, Argentině, Brazílii, na Kubě a v Kanadě. V roce 1924 se i toto torzo kapely pod vedením Košyce rozpadlo a její členové zůstali v USA. ${ }^{7}$ Někteř́ členové Košycovy skupiny však do Ameriky neodcestovali a natrvalo se usadili v Československu, kde dále vyvíjeli pedagogickou a uměleckou činnost. ${ }^{8}$

V samotném Brně hostovala kapela pouze při svém prvním československém turné. Ukrajinci se zde zastavili celkem na šest dní - od 20. do 25. května 1919. O jejich koncertní činnosti hojně informovaly místní noviny. První pozvánku na koncerty, které se měly konat 6 . a 7 . května, nacházíme 30 . dubna a 3. května v deníku Svoboda9 a záhy i v Lidových novinách: „Ukrajinská republikánská «kapela», která bude v Brně koncertovat dne 6. a 7. května, je pěvecký sbor, jaký byl svým časem Slavjanského, který před lety v Brně a na Moravě sklizel sensačni úspěchy. Není pochyby, že i tyto koncerty, které se konaji pod protektorátem ukrajinské vlády a mají za úkol seznámit Evropu s ukrajinskou lidovou písní, budou něčím nebývalým. I po vnějši stránce budou koncerty zajímavé tím, že všichni účinkujicí - 75 pánů a dam - budou ve svých nádherných krojich. [...]“.10 Koncerty plánované již na 6 . a 7. května se ovšem neuskutečnily. Kapela sice Brnem 1. května projížděla, ale musela zde absolvovat nepř́ijemnou policejní prohlídku, jelikož mezitím přišlo do Prahy udání, že do hlavního města mírí skupina, která má u sebe dva miliony nekolkovaných korun. Jednalo se ovšem o provokaci. Způsobili ji zřejmě užhorodští moskvofilové, kteří chtěli Ukrajincům uškodit. ${ }^{11}$ Po těchto nepř́ijemnostech a následném vysvětlení pokračovala kapela ihned v cestě do Prahy. V ranním vydání lidových novin z 6 . května, tedy ze dne, na který byl původně plánován první brněnský koncert, se v krátkém oznámení dozvíme, že se koncert Ukrajinců odkládá na 21. a 22. května, a že vstupenky již

7 ŠALPLACHTOVÁ, Zuzana. Hudební aktivity Ukrajincư v meziválečném a protektorátním Brně. Bakalářská diplomová práce, Masarykova univerzita, Filozofická fakulta, Ústav hudební vědy. Brno 2013. Vedoucí práce: Petr Kalina.

Jde zejména o Košycovu asistentku Platonidu Ščurovskou-Rosynevyč a pěvce Ninu a Hryce Ďačenkovi. Viz př́slušná hesla v Českém hudebním slovníku osob a instituci [online]. [Cit. 26. 9. 2013]. Dostupné z: <www.ceskyhudebnislovnik.cz/slovnik>.

9 Koncerty. Svoboda, 30. dubna 1919, roč. 1., č. 51, s. 4; Koncerty. Svoboda, 3. května 1919, roč. 1 , č. 53 , s. 3 .

10 Ukrajinská republikánská «kapela». Lidové noviny, ranní vydání, 3. května 1919, roč. 27, č. 122, s. 7.

11 БЕЗРУЧКО, Леонід. Украӥнська республіканська капела. Спогади з кониертної подорожі по Європі. Народна воля - The people’s will. Скрентон, 5. 3. 1932, № 26, с. 3. 
zakoupené zůstávají v platnosti. ${ }^{12} 14$. května se pak v Lidových novinách objevila zpráva o úspěchu kapely v Praze, která patrně reflektovala první pražský koncert ze dne 11. května: „Ukrajinští pěvci v Praze měli o svých koncertech ohromný úspěch. Koncertů zúčastnili se zastáncové velvyslanectev, vojenských misí, ministerstev atd. [...]. Hosté byli odměněni bour̆livým potleskem. V Brně budou koncertovat dne 21. a 22. května ve dvoraně Besedního domu [...]." "13 Ješš předtím než kapela přijela do Brna, informovaly Lidové noviny opakovaně o chystaných koncertech, jako by šlo o velkou událost $\mathrm{v}$ hudebním životě města. ${ }^{14}$ Přesto se však 20. května, tedy den před plánovaným vystoupením, objevila v Lidových novinách stručná zpráva: „Ukrajinské koncerty v Brně nebudou. Brněnské obecenstvo projevilo o koncerty tak málo zájmu, že bylo nutno je odř́ci. “"15

Právě v úterý 20. května přijela kapela do Brna. Podle svědectví jednoho z členů sboru Leonida Bezručka se umělci chtěli před polednem ubytovat $v$ hotelích a odpočinout si. Od vedení sboru se však dozvěděli, že v hotelích je jen 27 míst pro prominentní členy sboru a zbytek kapely bude muset spát v jistých kasárnách, které tehdy fungovaly coby naprosto neútulný lazaret. Vinou této události odmítli sboristé následující den zpívat, což zřejmě vysvětluje pravý důvod zrušení koncertu. Na druhý den se již podařilo zajistit všem ubytování v hotelu Slavia. ${ }^{16}$

Lidové noviny i následující den pokračovaly v propagaci koncertu, který se měl konat ve dvoraně besedního domu ${ }^{17}$ a poprvé se $\mathrm{k}$ nim připojila i Rovnost. ${ }^{18}$ 22. května pak Lidové noviny prrinesly krátké zhodnocení koncertního večera: „Koncert ukrajinského smiśseného sboru byl včera brněnskou sensaci v pravém, ale zároveň ušlechtilém smyslu toho slova. Ponechávajice odborný úsudek našemu hudebnímu referentovi, můžeme však zjistit, že dávno již žádný koncert neměl tak velký a zasloužený úspěch a nevzbudil tolik oprávněného nadšení jako koncert Ukrajinců, jejich hlasy, at' mužské či ženské jsou vzácné kvality, sbory a pisně úchvatné. Při mnohém koncertu bylo vidět kritiky spokojené a obyčejné obecenstvo rozmrzelé, jindy zas naopak. Tentokrát však svítily oči i kritikưm i obyčejným posluchačům opojením z ukrajinské zpěvni krásy. Dnes je druhý koncert. “" ${ }^{19}$ 23. května pak v Lidových novinách vyšla nepodepsaná, avšak rozsáhlá

12 Koncert Ukrajinců. Lidové noviny, ranní vydání, 6. května 1919, roč. 27, č. 125.

13 Ukrajinští pěvci v Praze. Lidové noviny, ranní vydání, 14. května 1919, roč. 26, č. 133, s. 5. Stejnou zprávu přinesl i deník Svoboda: Koncerty. Svoboda, 14. května 1919, roč. 1, č. 62, s. 4.

Denní zprávy. Lidové noviny, odpolední vydání, 15. května 1919, roč. 27, č. 134, s. 3; Ukrajinské koncerty budou. Lidové noviny, odpolední vydání, 17. května 1919, roč. 27, č. 136, s. 3; Ukrajinské koncerty budou. Lidové noviny, 18. května 1919, roč. 27, č. 137, s. 5.

15 Ukrajinské koncerty v Brně nebudou. Lidové noviny, ranní vydání, 20. května 1919, roč. 27, č. 139, s. 7 .

16 БЕЗРУЧКО, Леонід. Украӥнська республіканська капела. Спогади з концертної подорожі по Європі. Народна воля - The people’s will. Скрентон, 12. 3. 1932, № 29, s. 3.

17 Denní zprávy. Lidové noviny, 21. května 1919, roč. 27, č. 140, s. 3.

18 Koncerty Ukrajinců. Rovnost, 21. května 1919, roč. 35, č. 139, s. 4.

19 Koncert ukrajinského smíšeného sboru. Lidové noviny, ranní vydání, 22. května 1919, roč. 27, č. 141 , s. 5. 
recenze druhého koncertu z předešlého dne. Stat' je velmi pochvalná a zmiňuje i náročnost interpretace ukrajinských lidových písní s polyfonně vedenými hlasy. ${ }^{20}$ Obsáhlá recenze se objevila i ve Svobodě a přináší nejen svědectví o dobové recepci koncertu, ale také zajímavé detaily tohoto vystoupení, proto ji uvádíme $\mathrm{v}$ úplnosti:

„Milé hosty měli jsme ve středu v Brně v ukrajinském republikánském pěveckém sboru, který na umélecké pouti do Francie, Anglie a Ameriky, po velkých úspěších $v$ Praze a Plzni, udivil i nás svým svérázným a ohromujicím uměním. Ukrajinský sbor tento, organisovaný za propagačními účely ukrajinským ministerstvem uměni a národní kultury a čitajicí celkem asi 75 dam a pánů, otvírá nám výhledy do nového světa, prrináši nèco zcela odlišného od běžných našich produkcí pěveckých, podávaje nám rázovité a národně čisté výtvory lidového zpěvu svého, nám až dosud tak málo známého a snad i trochu podceňovaného bratrského národa ukrajinského. Stojíce pod podmanivým dojmem jich prvého koncertu brněnského, vidime bohužel teprve nyní jasně, co všechno jsme dř́ve ku své škodě neznali, a jak př́lišněe, všemi činiteli $k$ tomu jsouce vedeni, na vše pohliželi jsme německýma očima. Obdivujeme se tomu bratrství, prýštícimu z nevyvážené dosud studnice jich pisně lidové, napojené nitrem, srdcem i duši, slovanským hřejivým teplem a osobitou, ponejvice dumavou, více zamlklou než veselou náladou lidu ukrajinského. Z písní svého národa přednesli nám vzácní hosté v prvé radě písně náboženské a vážné, tak zvané kanty, psané namnoze pro sólové hlasy, které sbor jen harmonicky podporuje, pak básnè rázu méně vážnějšího, tak zvané koljady a ščedrovky. Vobou druzich těchto obráží se široká, čistá a krásná linie melodická, zbožnost a srdečnost lidu a kouzlojakési milé naivity, což vše souborem pưsobí s takovou bezprostředností, že podléháte př́mo účinnosti a dramatické až výraznosti lidových těchto projevů uměleckých. Pravé poklady tyto zpracovány jsou s neskonalou pietou po zachování jich pưvodnosti a velkým uměním a považovati dlužno upravovatele Lysenku, Košyce, Leontovyče, Stupnyčkyjho, Dernučkijho a j. za velké umělce, nejen s národy svými cítici a jeho perly milujicí, nýbrž $i$ za velké hudebníky vi̊bec, kteři $i$ v jiných oborech hudby jsou s to podati to nejlepší. Kéž z osobitějšich skladeb komponistů ukrajinských uslyšime v brzku více! Dirigent sboru p. Alexander Košyc jest sbormistrem temperamentním, který s obdivuhodnou až presností vše vypracovává, takže některé z podaných pisní byly prímo ideálně provedeny. Podporuje ho v tom ovšem zřejmá musikálnost zpěvákủ a pak jich sice necvičené, ale velké a zdravé hlasy, které poji se v celek okouzlujicího primo barvitostí a hutností, jimž dobrou základnou jsou jadrné ruské basy, které již svého času ve sboru nezapomenutelného Slavjanského byly tolik obdivovány. Nevskutku tajuplná pianisima střídaji se s přivaly sily mocného, však krásu zvuku neohrožujicího účinu. Jsme věru povděčni, že bylo umožněno vlastně v posledni chvili vystoupení Ukrajincư v Brně (koncerty vlastně již odřeknuty) a že seznali jsme v nich těleso tak vzácně disciplinované, vokalisace

20 Ukrajinský republikánský sbor. Lidové noviny, ranní vydání, 24. května 1919, roč. 27, č. 143, s. 2. 
bezvadné, čistoty téměr absolutni, rytmiky ostré a podání celkového plného citu a nehledanosti. Sboru takových kvalit nikdo nemũže upřiti zaslouženého uznání a jsme jisti, že budou přijati stejně vřele jako u nás i v celém světě. - Dvě kapek hořkosti nebylo nám však přece upreno: hosté zpivali vúborech salonnich, majice jakési potiže se svými zavazadly a tím ladný obraz pestrých krojů ukrajinských byl nám odepřen; dále oznámený sólista Alex. Nosalevič, který měl přednést ukázky písně umèlé, nespoluúčinkoval. Přes to posluchačstvo, kterého sešlo se velmi slušně, bylo ohromeno a zasypávalo hosty naše, jimž, jak jsme doslechli, nedostalo se $v$ Brně nejlepšiho pohostinství, obdivem a nadšeným uznáním. "21

Téhož dne se v odpoledním vydání Lidových novin objevila pozvánka na mimořádné matiné Ukrajinské lidové kapely, která také svědčí o nebývalém úspěchu jejích brněnských koncertů: „Ukrajinský pěvecký sbor rozhodl se po obrovském úspěchu obou koncertů uspoř́ádati v Brněv Besedním domě na všeobecnou žádost v neděli dne 25. t.m. o pưl 11. hod. dopoledne na rozloučenou matinée. Ukrajinci prišsli k nám a zvitézili na celé čárée. Doporučujeme nedělni matinée k návštěvě jmenovitě obyvatelstvu v okoli Brna a studentstvu. Poslechnouti krásné ukrajinské písně v nedostižném provedení patř́ k nezapomenutelným dojmům. Mimo to akt slovanské vzájemnosti veli poslechnout milé hosty. Ceny za matinée značně sniženy [...]. Konec matinée před půl 1., což je výhodou pro účastniky $z$ venkova. Program je zcela nový."22

Ukrajinská republiková kapela tedy $\mathrm{v}$ Brně strávila šest dní a uspořádala tři neobyčejně úspěšná vystoupení (21., 22. a 25. května 1919), která na publikum zanechala značný dojem. Z Brna vedla jejich cesta přes Prostějov, Olomouc a Chrudim zpět do Prahy. $Z$ dobových svědectví je zřejmé, že koncerty tohoto sboru vytvořily časově sice epizodní, ale přesto významnou součást hudebního života našeho města. Je rovněž nepochybné, že vystoupení nebyla směřována na úzkou skupinu Ukrajinských krajanů (těch konečně v roce 1919 nebylo ještě v Brně usazeno mnoho), nýbrž na široké publikum z řad české veřejnosti. V archivu Slovanské knihovny Národní knihovny České republiky je uchovávána rukopisná Pamětní knižka Ukrajinské republikové kapely, do níž se podepisovali a nezř́íka dělili svými dojmy návštěvníci koncertů, a to po celou dobu existence kapely. Na stránce vyhrazené pro reakce z brněnských koncertů nacházíme např. príípisy a podpisy malíŕky Zdenky Vorlové-Vlčkové, skladatele Viléma Petrželky, pedagoga brněnské konzervatoře Rudolfa Reissiga, nebo významného klavírního pedagoga Viléma Kurze, který v té době končil své jednadvacetileté angažmá na konzervatoři ve Lvově. ${ }^{23}$

\footnotetext{
21 Ukrajinský sbor. Svoboda, 23. května 1919, roč. 1, č. 70, s. 2.
}

22 Matinée Ukrajinců. Lidové noviny, odpolední vydání, 24. května, roč. 27, č. 143, s. 5. Další pozvánka se v Lidových novinách objevila také v den konání matiné: Dnes matinée Ukrajinců. Lidové noviny, ranní vydání, 25. května, roč. 27, č. 144. Na dopolední koncert zvala také Svoboda: Koncerty. Svoboda, 24. května 1919, roč. 1, č. 71, s. 4.

23 Пам'ятна книга Украӥнської республіканської капели. Лл. 1919-. Slovanská knihovna Národní knihovny České republiky, sig. U9440, T-A 2558, s. 11 rkp. 


\section{Hudební vystoupení ukrajinských krajanských spolků}

Od začátku 20. let začíná v Brně, stejně jako v jiných regionech Československa, pomalu stoupat počet emigrantů z Ukrajiny. ${ }^{24}$ Jejich odchod souvisel především s pádem Ukrajinské lidové republiky, na jejím území byla ustanovena Ukrajinská sovětská republika a s připojením Západoukrajinské lidové republiky k Polsku. Právě Československo bylo pro ukrajinské vystěhovalce častým cílem, jelikož právě zde byla roku 1921 ustanovena vládou podporovaná Ruská pomocná akce, která umožňovala materiální zázemí především pro emigranty z někdejšího carského Ruska. ${ }^{25}$ Kromě řady profesních, zájmových nebo uměleckých asociací tak začaly vznikat i celé vzdělávací ústavy určené právě emigrantům. Nejživější emigrantský život nacházíme v Praze, kde sídlilo nejvíce těchto institucí, významným centrem ukrajinské inteligence byly rovněž Poděbrady, kde sídlila Ukrajinská hospodářská akademie. ${ }^{26}$ Několik krajanských spolků bylo založeno rovněž v Brně. K jejich nejčastějším aktivitám patřilo pořádání osvětových přednášek a také kulturní činnost, která měla nejen samotnou diasporu, ale také širší místní veřejnost upozorňovat na bohatou uměleckou tradici ukrajinského národa.

Omezíme-li mapování ukrajinských kulturních setkání v Brně pouze na ty, v nichž byla nějakým způsobem zastoupena hudba, nacházíme první takovou akci 18. března 1922. Měsíce březen a duben byly pro ukrajinskou národně smýšlející uměleckou frontu už od druhé poloviny 19 . století nejaktivnějším obdobím roku. Na březen totiž připadají výročí narození i úmrtí největšího ukrajinského básníka Tarase Hryhorovyče Ševčenka (1814-1861), který se pro Ukrajince stal symbolem boje za kulturní, jazykovou i politickou emancipaci jejich národa. Onoho dne se ve výstavním sále Vysoké školy zemědělské uskutečnila slavnostní ševčenkovská akademie. Akci organizovala Ukrajinská akademická hromada. ${ }^{27} \mathrm{Na}$ programu byly deklamace Ševčenkových básní a sborová vystoupení se skladbami klasiků ukrajinské hudby Mykoly Lysenka, Nestora Nyžankivského, Stanislava Ljudkevyče a Sydora Vorobkevyče. Sbor dirigoval jistý „starší veterinář Al. Bileckyj“. Na akademii se vybíraly dobrovolné př́spěvky na ukrajinskou akademii věd v Kyjevě. ${ }^{28}$

24

ZILYNSKYJ, Bohdan. Ukrajinci v Čechách a na Moravě (1894) 1917-1945 (1994). X-EGEM. s.r.o, Praha, 1995.

Русская акция помощи в Чехословакии. История, значение, наследие. Национальная библиотека Чешской Республики - Славянская библиотека, Гражданское объединение «Русская традиция», Прага 2012.

ZILYNSKYJ, Bohdan. Ukrajinci v Čechách a na Moravě (1894) 1917-1945 (1994). X-EGEM. s.r.o, Praha, 1995.

Spolek ukrajinských studentů s názvem Ukrajinská akademická hromada v Československé republice v Brně (Українська академічна громада в Чехословацькій республіці в Брні) se sídlem v Brně vznikl 26. 6. 1921 a v roce 1923 se přejmenoval na Ukrajinskou akademickou hromadu v Brně v ČSR. Viz Moravský zemský archiv, fond Policejní ředitelství Brno, karton 2650 , č. j. 35026.

Národní archiv, fond Ukrajinské muzeum, karton 84, inv. č. 1014. 
V roce 1923 pak bylo v Brně možné setkat se s ukrajinskou hudbou na slavnostní akademii studentských Majáles. Pořadatelem byla znovu Ukrajinská akademická hromada a na programu nejen skladby Ukrajinců Lysenka a Nižanskivského, ale také Česká balada Otakara Ostrčila a tři výstupy z oper Bedřicha Smetany. Zpíval pražský Ukrajinský akademický sbor, který vedla již zmíněná někdejš́ asistentka Oleksandra Košyce Platonida Ščurovská, ${ }^{29}$ zúčastnili se však také čeští umělci: na klavír doprovázel tehdejší Janáčkův žák a kapelník brněnské opery Břetislav Bakala, sólové či ansámblové party českých skladeb přednesl člen Pěveckého sdružení moravských učitelů František Voda a pozdější barytonista brněnské opery Ferdinand Minařík. ${ }^{30}$

$\mathrm{V}$ tomtéž roce se 21. listopadu konal koncert v brněnském Besedním domě. Akce se uskutečnila pod protektorátem spolku Slavjan. Vystoupil zde tehdejší první tenorista opery v Záhřebu Roman Ljubineckyj a někdejší absolvent mistrovské kompoziční tř́́dy Vítězslava Nováka skladatel a klavírista Vasyl Barvinskyj, jenž $\mathrm{v}$ té době působil jako ředitel Lysenkovy hudební konzervatoře ve Lvově. Brněnský koncert byl součástí československého turné obou umělců. ${ }^{31}$ Na programu byla díla Denyse Sičinského, Stanislava Ljudkevyče, Mykoly Stepového, Vasyla Barvinského, Mykoly Lysenka a árie z oper Smetany a Masseneta, které Ljubineckyj zpíval chorvatsky. Výtěžek koncertu šel na podporu ukrajinských studentů v Československu. Zachovaný program koncertu obsahuje české transkripce textů ukrajinských písní; ${ }^{32}$ akce byla tedy určena nejen krajanskému, nýbrž i českému publiku.

19. března 1925 se ve velkém sále Besedního domu konal další z ševčenkovských koncertů. Jeden z místních studentských pěveckých sborů zde zpíval písně Jaroslava Jaroslavenka, Kyryla Stecenka a Mykoly Lysenka. Dále vystoupla sólistka užhorodského divadla Anda Ostapčuk, která oblečena do národního kroje, zpívala za doprovodu klavíru lidové písně. Významným hostem večera byl Vasyl Jemecdůležitý představitel ukrajinské hudební emigrace do Československa, propagátor hry na ukrajinský lidový chordofon banduru a širritel repertoáru kobzarů a banduristů. O akci informoval ukrajinský lvovský deník Dilo; podle této recenze nejvíce publikum zaujalo právě Jemcovo vystoupení. ${ }^{33}$ Díky archivním spisům z Policejního ředitelství máme zachován kompletní program akce a také se dozvídáme, že pořadatelem koncertu byla opět Ukrajinská akademická hromada v Brně. ${ }^{34}$

29 KALINA, Petr Ch. Ščurovska, Platonida Ivanivna. In Český hudební slovník osob a institucí [online]. [Cit. 27. 9. 2013]. Dostupné z: $<$ http://www.ceskyhudebnislovnik.cz/slovnik/index. php?option $=$ com_mdictionary\&action $=$ record_detail\&id $=1003395>$.

30 Národní archiv, fond Ukrajinské muzeum, karton 84, inv. č. 1014.

31 KALINA, Petr Ch. Barvinskyj, Vasyl Oleksandrovyč. In Český hudební slovnik osob a institucí [online]. [Cit. 27. 9. 2013]. Dostupné z: < http://www.ceskyhudebnislovnik.cz/slovnik/ index.php?option $=$ com_mdictionary\&action $=$ record_detail\&id $=1003391>$.

32 Národní archiv, fond Ukrajinské muzeum, karton 84, inv. č. 1014.

33 Шевченківський концерт у Берні моравськім. Діло, 1925, с̌.. 70 (29. 3.), s. 3.

34 Moravský zemský archiv, fond Policejní ředitelství Brno, karton 2650, č. j. 35026. 
Dle spisů Policejního ředitelství uspořádal 10. března 1927 na Komenského náměstí 14 (dnes Burianovo náměstí v Brně-Žabovřeskách) ${ }^{35}$ Ukrajinský spolek Tarase Ševčenka v Brně slavnostní akademii k 66. výročí úmrtí tohoto ukrajinského básníka. Před slavností se konala valná hromada zmíněného levicového krajanského spolku. Akademie byla složená z projevů a referátů na ševčenkovská témata, recitací, sborových zpěvů lidových písní, zpěvu Ševčenkových zhudebněných básní a z instrumentálních výstupů. Oslava končila zapěním Internacionály. ${ }^{36}$

Jiné ševčenkovské oslavy v Brně se konaly 27. dubna 1929. Pořadatelem byla Ukrajinská akademická hromada. Místo konání bohužel neznáme. Úvodní slovo na téma Taras Ševčenko jako prorok národni Ukrajiny pronesl předseda Ukrajinské hromady Andrij Škvarko. Dále zazněl referát na téma Ševčenko ukrajinské armádě gymnaziálního učitele Ilko Kaličaka. Hudební složku oslav tvořilo vystoupení sboru pod vedením absolventa techniky Andreje Ševce. Tři sólové písně zazpívala inženýrka chemie slečna Žolkivska. Poté student techniky Bajka deklamoval Ševčenkovu báseň Son, studentka brněnské medicíny slečna Martynčukivna z Užhorodu přednesla báseň Kavkaz téhož autora. Z vybraného vstupného byla část poslána organizacím na Ukrajině. O akci informoval lvovský deník Dilo. ${ }^{37}$

V Katolickém domě v Brně-Králově Poli se dále dne 29. března 1930 konal ševčenkovský koncertní večer, který pořádala Ukrajinská akademická hromada. Kromě proslovů a deklamací na akci zapíval pěvecký sbor, a to zhudebněné verše Tarase Ševčenka. Z dokumentu z archivu Policejního ředitelství se mj. dočteme, že se akce konala ,za účasti asi 80 osob a všech společenských tř́d ukrajinské národnosti. “38

V novinách Dilo se dozvídáme, že 30. května 1933 vysílal brněnský rozhlas živě sbory, které zazněly na akademii k poctě Ševčenka. Akci organizovala „ukrajinská kolonie““. ${ }^{39}$ Na rozhlasový pořad o Ukrajině (Taras Ševčenko, básník Ukrajiny) upozornily formou otištění rozhlasového programu opakovaně i Lidové noviny. ${ }^{40}$ V rozhlasovém týdeníku Radiojournal pak lze dohledat podrobný program tohoto vysílání:

„Taras Ševčenko, básnik Ukrajiny:

Taras Ševčenko: Povoláni Šafařovicovi z básně Jan Hus... Recituje Otto Čermák

35 FLODROVÁ, Milena. Brněnské ulice a vývoj jejich názvů od 13. století po dnešek. Brno, 1997.

36 Moravský zemský archiv, fond Policejní ředitelství Brno, karton 2650.

37 Шевченківське свято у Брні. Діло, 1929, с̌. 140 (18. 5.), s. 4.

38 Moravský zemský archiv, fond Policejní ředitelství Brno, karton 2650, č. j. 35026.

39 Академія в честь Шевченка у Брні. Діло, 1933, с̌. 140 (2. 6.), s. 3.

40 Lidové noviny, odpolední vydání, 29. května 1933, roč. 41, č. 270, s. 3; Lidové noviny, ranní vydání, 30. května 1933, roč. 41, č. 271, s. 9; Lidové noviny, odpolední vydání, 30. května 1933, roč. 41, č. 272 , s. 5 . 
Básníkův profil... Spis. Ol. Zemek

Národni ukrajinské pisně: a) Zapovit' (Závět'), b) Oj, mema, mema... Zpivá sbor ukrajinských studentů

O. Zemek: Kobzar, epická báseñ... Rec. Otto Čermák

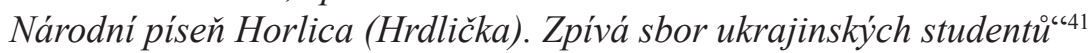

Československo-ukrajinská jednota uspořádala o pravoslavných vánocích 6. ledna 1935 na brněnském Stadionu prátelský večer spojený s oslavou 70. narozenin předsedy spolku, někdejšího rektora Vysoké školy zvěrolékařské prof. Antonína Hrůzy. Na akci zazpíval ukrajinský mužský pěvecký sbor a zazněla klavírní Preludia Vasyla Barvinského a klavírní skladba Šumka Mychajla Zavadského. Kromě toho se zpívaly ukrajinské koledy. Přítomní jubilantovi gratulovali jako prŕteli ukrajinského lidu. O akci informovalo lvovské Dilot2 a brněnské Lidové noviny.$^{43}$ Oslava narozenin prof. Hrůzy z brněnské veterinární školy byla pro brněnské Ukrajince poměrně významnou, nebot' právě na této vysoké škole studovalo ukrajinských studentů nejvíce. ${ }^{44} \mathrm{~V}$ souvislosti s ukrajinskými spolky v Brně byl Hrůza výraznou postavou, nebot' stál v čele Československo-ukrajinské jednoty v Brně od 7. června 1933 do 16. června 1937, kdy dobrovolně odstoupil. Jako předseda spolku se velkou měrou podílel na kulturním životě a možnostech vzdělávání Ukrajinců, kteří v této době v Brně a okolí žili. Je dochováno několik Hrůzových rukopisů, v nichž svolává rodiče dětí navštěvujících české školy, aby prrišli na schůzi ohledně kurzů ukrajinštiny, ukrajinské literatury a ukrajinských dějin, které spolek pro děti pořádá. ${ }^{45}$ Je tedy zrejmé, že Čech Antonín Hrůza byl pro Ukrajince působící v prvorepublikovém Brně skutečně důležitou osobou.

Hrůzova Česko-ukrajinská jednota nedlouho poté uspořádala veřejnou tryznu za nedávno zesnulého historika, předsedu ukrajinské Centrální rady a bojovníka za nezávislou ukrajinskou státnost Mychajla Hruševského. Akce se konala 20. ledna 1935 v Masarykově studentském domě za účasti rektora Masarykovy univerzity, rektora Vysoké školy zemědělské, zástupců krajské školní rady, nejvyššího soudu, města ad. Na akci zpíval ukrajinský mužský sbor pod vedením inženýra Volodymyra Franteka ukrajinské pohřební písně. O události druhý den informovaly Lidové noviny ${ }^{46}$ a později i Dilo. ${ }^{47}$

Tatáž společnost uspořádala 6. dubna 1935 oslavu stého výročí narození romantického spisovatele Osypa Jurije Fed'kovyče (1834-1888). Slavnost ve formě

\footnotetext{
41 Radiojournal, roč. 10, č. 22 (27. května 1933), s. 16.

423 життя українців у Чехословаччині. Діло, 1935, с̌.. 19 (25. 1.), s. 4-5.

43 Československo-ukrajinská jednota v Brně, Lidové noviny, ranní vydání, roč. 43, č. 7, s. 7.

44 ZILYNSKYJ, Bohdan. Ukrajinci v Čechách a na Moravě (1894) 1917-1945 (1994). X-EGEM. s.r.o, Praha 1995.

45 Moravský zemský archiv, fond Policejní ředitelství Brno, karton 3136, č. j. 7492/47.

46 Tryzna za Mychajla Hruševského. Lidové noviny, ranní vydání, 21. ledna 1935, roč. 43, č. 36, s. 5.

473 життя українців у Чехословаччині. Діло, 1935, с̌. 19, s. 4-5.
} 
koncertu se konala ve velkém sále Besedního domu a vystoupil na ní ukrajinský mužský sbor opět pod vedením Volodymyra Franteka, violoncellista prof. Bohdan Berežnyckyj a klavíristka Darija Karanovyčeva z Vídně, dále Anda Ostapčuk-Naumenko (zmínili jsme již jako sólistku užhorodského divadla na koncertě 19. března 1925; v roce 1935 již působila ve slovenské Nitře). Na repertoáru byly skladby Vasyla Barvinského, Stanislava Ljudkevyče, Ostapa Nyžankivského, Viktora Kosenka a lidové zpěvy, zejména huculské, tedy z Fed'kovyčovy domoviny. Malou část koncertu přenášel brněnský rozhlas. ${ }^{48} \mathrm{Na}$ akci v předstihu opakovaně zvaly Lidové noviny, ${ }^{49}$ které později celou akci recenzovaly; ${ }^{50} \mathrm{o}$ konání akce informovalo ve Lvově rovněž Dilo. ${ }^{51}$

Následujícího dne 7. dubna 1935 odjeli hosté oslav na Macochu, kde Anda Ostapčuk-Naumenko zazpívala další část svého repertoáru. Tento její výstup, který byl dle zachovaného programu složen z úprav ukrajinských lidových písní Lysenka, Barvinského, Stecenka a dalších, opět přenášel brněnský rozhlas. ${ }^{52}$ Výjimečné na této situaci je, že brněnské studio věnovalo dva dny po sobě třicet minut své vysílací doby ukrajinské hudbě, což je v celých dějinách této rozhlasové stanice skutečně ojedinělé.

Další ševčenkovská slavnost ukrajinské komunity v Brně se uskutečnila 24. dubna 1937. Kromě proslovů a deklamací zde zněly původní skladby a úpravy lidových písní Mykoly Lysenka, Vladyslava Zaremby a Vasyla Barvinského. Jako interpreti se na koncertě podíleli manželé Nina a Hryc Ďačenkovi - jedni z pohrobků Košycovy Ukrajinské republikové kapely, kteří po jejím rozdělení zůstali v Československu a výrazně se podíleli na hudebním životě ukrajinské diaspory. Byli však činí i v českém hudebním provozu, a to zejména coby sboristé olomoucké opery. ${ }^{53} \mathrm{O}$ slavnosti informovalo pouze Dilo. ${ }^{54}$

Poslední akce se zastoupenou hudební složkou, kterou máme u ukrajinské diaspory v meziválečném Brně doloženou, se konala o den později, tedy 25 . dubna 1937. Jednalo se o den pro děti, který zorganizovalo ukrajinské sdružení Jednota (Єдність). Pod vedením paní E. Gottfriedové byla představena divadelní hra pro děti s názvem Živé loutky od spisovatele Mykoly Šuhajevského. Představení bylo

Radiojournal, roč. 13, číslo 13, 30. března 1935, s. 35.

Večer ukrajinské písně a hudby. Lidové noviny, 5. dubna 1935, ranní vydání, roč. 43, č. 174, s. 3; Večer ukrajinské písně a hudby. Lidové noviny, 6. dubna 1935, ranní vydání, roč. 43, č. 176, s. 8; Večer ukrajinské písně a hudby. Lidové noviny, 6. dubna 1935, odpolední vydání, roč. 43 , č. 177 , s. 9.

Večer ukrajinské hudby. Lidové noviny, ranní vydání, 9. dubna 1935, roč. 43, č. 181, s. 9.

3 життя українців у Брні Моравськім. Діло, 1935 с̌. 104 (20. 4.), s. 5.

Radiojournal, roč. 13, č. 14, 6. dubna 1935, s. 5.

KALINA, Petr Ch. Ďačenko, Hryc. In Český hudebni slovník osob a institucí [online].[Cit. 29.9. 2013]. Dostupné z: $<$ http://www.ceskyhudebnislovnik.cz/slovnik/index.php?option=com_mdictionary\&action=record_detail\&id=2211>; KALINA, Petr Ch. Ďačenko, Nina. In Českýhudební slovník osob a institucí [online]. [Cit. 29.9. 2013]. Dostupné z: $<$ http://www.ceskyhudebnislovnik. cz/slovnik/index.php?option=com_mdictionary\&action=record_detail\&id=3063>.

ВІТРОВСЬКИЙ, Л. 3 українського життя у Брні, Ч.С.Р. Діло, 1937, с̌. 99 (9. 5.), s. 4. 
hráno v češtině, což mělo prohloubit česko-ukrajinské vztahy. Následoval čajový večírek pro dospělé, kde byly předvedeny ukrajinské tance. Místem konání byl sál Sportovního klubu v Židenicích. K divadelnímu představení a následně $\mathrm{k}$ tanci hrál smyčcový orchestr pod vedením jistého V. Najdy. Tyto informace se dozvídáme pouze z deníku Dilo. ${ }^{55}$

Dále v dobových dokumentech uložených zejména v Národním archivu nacházíme informace o konání několika hudebních akcích v Brně spadajících do období Protektorátu Čechy a Morava. Ty však již přesahují časový rámec vymezený pro naši studii.

$\mathrm{Z}$ dostupných materiálů lze usoudit, že hudební život Ukrajinců v meziválečném Brně nebyl nijak zvlášt' pestrý ani bohatý. Přesto však za jednotlivými akcemi můžeme vidět snahu zástupců ukrajinské komunity v Brně o oživení vlastního kulturního dědictví; jejich úsilí byla primárně směrována bud' dovnitř svého společenství, nebo k majoritní brněnské societě. Je třeba si uvědomit, že šlo z valné většiny o osamělé politické emigranty, kteří věřili v konečné pozitivní vyústění politického dění ve své vlasti, at' už pocházeli z východní Ukrajiny, kterou zachvátila sovětská moc, nebo z Ukrajiny západní, kde byla po neúspěšném pokusu o emancipaci po první světové válce opětovně nastolena polská vláda. V atmosféře formování novodobých národních států po první světové válce, kdy vzniklo mj. i Československo, se Ukrajincům formou koncertů Ukrajinské republikové kapely sice načas podařilo obrátit pozornost širší české veřejnosti k ukrajinské otázce, další akce upozorňující na existenci svébytné ukrajinské kultury se pak nejen v Brně potkávaly bud's nulovým, nebo jen okrajovým zájmem českého publika i českých médií. Překvapivě bohatá a v jistých ohledech neobyčejně pozoruhodná hudební kultura Ukrajiny zůstává bohužel i naší dnešní veřejností nadále takřka nepovšimnuta.

Petr Ch. Kalina (kalina@phil.muni.cz) vystudoval v roce 2003 Hudební vědu a Ukrajinistiku na Filozofické fakultě Masarykovy univerzity. Roku 2010 obhájil na téže fakultě disertační práci v oboru Hudební věda. Na domovské fakultě působí jako odborný pracovník Ústavu hudební vědy a také coby odborný asistent Ústavu slavistiky. Soustavně se zabývá hudební kulturou slovanských národů (zejména Ukrajinců a Lužických Srbů) se zvláštním zřetelem k hudebnímu folklóru a k organologické problematice. Jako dlouholetý redaktor Českého hudebního slovníku osob a institucí je rovněž činný v oblasti hudební lexikografie.

Zuzana Šalplachtová (361607@mail.muni.cz) je čerstvou absolventkou bakalářského cyklu oborů Hudební věda a Ukrajinistika na Filozofické fakultě Masarykovy univerzity. Ve své juvenilní odborné činnosti reflektuje především ukrajinskou hudební kulturu, a to zejména historicko-systematické aspekty kompoziční činnosti Mykoly Lysenka a hudební aktivity Ukrajinců v prostředí jižní Moravy. 


\section{ABSTRACT MUSICAL ACTIVITIES OF THE UKRAINIANS IN INTERWAR BRNO}

The study focuses on the historical evaluation of the role of the Ukrainians in interwar Brno's overall cultural environment. The Moravian metropolis played an important part in the lives of the Ukrainian diaspora in Czechoslovakia. Themes in the study are dealt with in two chronologically linked areas - both the production of the Ukrainian artists who visited Brno as guests (Ukrainian republic band in 1919) and the later musical activity connected with federal activities of the Ukrainians settled in Brno are introduced. Ukrainian music production in interwar Brno was, with some exceptions, for a broad audience, it was also for a number of times broadcasted on the Brno radio. Although these musical performances did not quantitatively exceed those in Prague, many of them were of a high artistic level. The study is another piece in mapping of the musical lives of the Ukrainians in interwar Czechoslovakia and it also brings new findings about musical course of events in Brno in the first republic era.

\section{Key words}

Brno; Czechoslovakia; Ukrainian music; emigration; Ukrainian republic band

\section{Bibliography}

Československo-ukrajinská jednota v Brně. Lidové noviny, ranní vydání, roč. 43, č. 7, s. 7.

Denní zprávy. Lidové noviny, 21. května 1919, roč. 27, č. 140, s. 3.

Denní zprávy. Lidové noviny, odpolední vydání, 15. května 1919, roč. 27, č. 134, s. 3; Ukrajinské koncerty budou. Lidové noviny, odpolední vydání, 17. května 1919, roč. 27, č. 136, s. 3.

Dnes matinée Ukrajinců. Lidové noviny, ranní vydání, 25. května, roč. 27, č. 144.

FLODROVÁ, Milena. Brněnské ulice a vývoj jejich názvio od 13. století po dnešek. Brno, 1997.

KALINA, Petr Ch. Barvinskyj, Vasyl Oleksandrovyč. In Český hudebni slovnik osob a institucí [online]. [Cit. 27. 9. 2013]. Dostupné z: < http://www.ceskyhudebnislovnik.cz/slovnik/index.php?option=com_mdictionary\&action=record_detail\&id=1003391>.

KALINA, Petr Ch. Ďačenko, Hryc. In Český hudební slovník osob a institucí [online].[Cit. 29. 9. 2013]. Dostupné z: <http://www.ceskyhudebnislovnik.cz/slovnik/index.php?option=com_mdictionary\&action=record_detail\&id=2211>.

KALINA, Petr Ch. Košyc, Oleksandr Antonovyč. In Český hudební slovnik osob a institucí [online]. [Cit. 26. 9. 2013]. Dostupné z: $<$ http://www.ceskyhudebnislovnik.cz/slovnik/index.php?option $=$ com_mdictionary\&action=record_detail\&id=1003925>.

KALINA, Petr Ch. Ščurovska, Platonida Ivanivna. In Český hudební slovník osob a institucí [online]. [Cit. 27. 9. 2013]. Dostupné z: <http://www.ceskyhudebnislovnik.cz/slovnik/index.php?option $=$ com_mdictionary\&action=record_detail\&id $=1003395>$.

KALINA, Petr Ch. Ukrajinská republiková kapela. In Český hudebni slovnik osob a institucí [online].[Cit. 26. 9. 2013]. Dostupné z: <http://www.ceskyhudebnislovnik.cz/slovnik/index.php?option $=$ com_mdictionary\&action=record_detail\&id=1003929>.

Koncert Ukrajinců. Lidové noviny, ranní vydání, 6. května 1919, roč. 27, č. 125.

Koncert ukrajinského smíšeného sboru. Lidové noviny, ranní vydání, 22. května 1919, roč. 27, č. 141, s. 5.

Koncerty Ukrajinců. Rovnost, 21. května 1919, roč. 35, č. 139, s. 4.

Koncerty. Svoboda, 30. dubna 1919, roč. 1., č. 51, s. 4.

Koncerty. Svoboda, 3. května 1919, roč. 1, č. 53, s. 3.

Koncerty. Svoboda, 14. května 1919, roč. 1, č. 62, s. 4.

Koncerty. Svoboda, 24. května 1919, roč. 1, č. 71, s. 4.

Lidové noviny, odpolední vydání, 29. května 1933, roč. 41, č. 270, s. 3. 
Lidové noviny, ranní vydání, 30. května 1933, roč. 41, č. 271, s. 9.

Lidové noviny, odpolední vydání, 30. května 1933, roč. 41, č. 272, s. 5.

Matinée Ukrajinců. Lidové noviny, odpolední vydání, 24. května, roč. 27, č. 143, s. 5.

Moravský zemský archiv, fond Policejní ředitelství Brno, karton 2650, č. j. 35026.

Moravský zemský archiv, fond Policejní ředitelství Brno, karton 3136, č. j. 7492/47.

Národní archiv, fond Ukrajinské muzeum, karton 84, inv. č. 1014.

NEJEDLÝ, Zdeněk. Ukrajinská republikánská kapela. Kyjev-Praha: Čas, 1920.

Radiojournal, roč. 10, č. 22, 27. května 1933, s. 16.

Radiojournal, roč. 13, č. 13, 30. března 1935, s. 35.

Radiojournal, roč. 13, č. 14, 6. dubna 1935, s. 5.

ŠALPLACHTOVÁ, Zuzana. Hudebni aktivity Ukrajinců v meziválečném a protektorátním Brnè.

Bakalářská diplomová práce, Masarykova univerzita, Filozofická fakulta, Ústav hudební vědy.

Brno 2013. Vedoucí práce: Petr Kalina.

Tryzna za Mychajla Hruševského. Lidové noviny, ranní vydání, 21. ledna 1935, roč. 43, č. 36, s. 5.

Ukrajinská republikánská «kapela». Lidové noviny, ranní vydání, 3. května 1919, roč. 27, č. 122, s. 7.

Ukrajinské koncerty budou. Lidové noviny, 18. května 1919, roč. 27, č. 137, s. 5.

Ukrajinské koncerty v Brně nebudou. Lidové noviny, ranní vydání, 20. května 1919, roč. 27, č. 139, s. 7.

Ukrajinský republikánský sbor. Lidové noviny, ranní vydání, 24. května 1919, roč. 27, č. 143, s. 2.

Ukrajinský sbor. Svoboda, 23. května 1919, roč. 1, č. 70, s. 2.

Ukrajinští pěvci v Praze. Lidové noviny, ranní vydání, 14. května 1919, roč. 26, č. 133, s. 5.

Večer ukrajinské písně a hudby. Lidové noviny, 5. dubna 1935, ranní vydání, roč. 43, č. 174, s. 3.

Večer ukrajinské hudby. Lidové noviny, ranní vydání, 9. dubna 1935, roč. 43, č. 181, s. 9.

Večer ukrajinské písně a hudby. Lidové noviny, 6. dubna 1935, odpolední vydání, roč. 43, č. 177, s. 9.

Večer ukrajinské písně a hudby. Lidové noviny, 6. dubna 1935, ranní vydání, roč. 43, č. 176, s. 8.

VESELÁ, Jitka. Ukrajinská republikánská kapela a jeji působení v Československu v roce 1919.

Bakalářská diplomová práce, Univerzita Karlova v Praze, Filozofická fakulta, Ústav slavistických a východoevropských studií. Praha 2010. Vedoucí práce: Tereza Chlaňová.

ZILYNSKYJ, Bohdan. Ukrajinci v Čechách a na Moravě (1894) 1917 - 1945 (1994). X-EGEM. s.r.o, Praha, 1995.

Академія в честь Шевченка у Брні. Діло, 1933, с̌. 140 (2. 6.), s. 3.

БЕЗРУЧКО, Леонід. Українська республіканська капела. Спогади з конщертної подорожі по Європі. Народна воля - The people’s will. Скрентон, 9. 4. 1932, № 41, s. 3.

БЕЗРУЧКО, Леонід. Українська республіканська капела. Спогади з конщертної подорожі по Європі. Народна воля - The people’s will. Скрентон, 5. 3. 1932, № 26, с. 3.

БЕЗРУЧКО, Леонід. Українська республіканська капела. Спогади з концертної подорожі по Європі. Народна воля - The people's will. Скрентон, 12. 3. 1932, № 29, s. 3.

ВІТРОВСЬКИЙ, Л. 3 українського життя у Брні, Ч.С.Р. Діло, 1937, с̌. 99 (9. 5.), s. 4.

3 життя українців у Брні Моравськім. Діло, 1935 с̌. 104 (20. 4.), s. 5.

3 життя українців у Чехословаччині. Діло, 1935, с̌. 19, s. 4-5.

Пам'ятна книга Украӥнської республіканської капели. Лл. 1919-. Slovanská knihovna Národní knihovny České republiky, sig. U9440, T-A 2558, s. 11 rkp.

Русская акиия помощи в Чехословакии. История, значение, наследие. Национальная библиотека Чешской Республики - Славянская библиотека, Гражданское объединение «Русская традиция», Прага 2012.

Шевченківське свято у Брні. Діло, 1929, с̌. 140 (18. 5.), s. 4.

Шевченківський концерт у Берні моравськім. Діло, 1925, с̌.. 70 (29. 3.), s. 3. 